\title{
Nutritional Composition of Developed Value-Added Pizza Base using Whole Wheat Flour, Quinoa Flour and Lotus Stem Powder
}

\author{
Saini Manju ${ }^{1 *}$, Wadhawan Nikita ${ }^{2}$ and Lakhawat Sarla ${ }^{1}$ \\ ${ }^{1}$ Department of Food Science and Nutrition, College of Community and Applied Sciences, \\ MPUAT, Udaipur, Rajasthan, India \\ ${ }^{2}$ Department of Renewable Energy and Engineering, College of Technology and Engineering, \\ MPUAT, Udaipur, Rajasthan, India \\ *Corresponding author
}

A B S T R A C T

\begin{tabular}{l} 
K e y w o r d s \\
$\begin{array}{l}\text { Quinoa flour, Lotus } \\
\text { stem powder, Value } \\
\text { added pizza base, } \\
\text { Nutritional } \\
\text { composition }\end{array}$ \\
\hline Article Info \\
\hline $\begin{array}{l}\text { Accepted: } \\
\text { 20 June 2021 } \\
\text { Available Online: } \\
\text { 10 July 2021 }\end{array}$ \\
\hline
\end{tabular}

Keywords

Quinoa flour, Lotus stem powder, Value added pizza base Nutritional composition

Accepted: 20 June 2021 Available On
Junk foods can be a treat to the taste buds, but the ill effects of these foods are widely known. Its regular consumption can have adverse effects on our health and may cause irreparable damage to the body. Several scientific researchers have proven that junk food can leave one prone to heart diseases and may eventually make the brain weak and nonfunctional. The role of nutrient rich junk food in offering protection against diabetes and heart disease is well established for this reason interest has arisen in increasing nutrients in developed pizza base. The present research has been conducted to develop and standardize "value added pizza base" made using wheat flour, quinoa flour \& lotus stem powder. The developed pizza base has advantages over normal base made from refined wheat flour. According to objective four different value added pizza base samples named as $T_{0}, T_{1}, T_{2}$, $\mathrm{T}_{3}, \mathrm{~T}_{4}$ were developed for evaluation purpose. $\mathrm{T}_{0}$ (control) was made with 100 percent of whole wheat flour and Treatment $\mathrm{T}_{1}, \mathrm{~T}_{2}, \mathrm{~T}_{3}, \mathrm{~T}_{4}$ was made by incorporating wheat flour, quinoa flour and lotus stem powder in different ratio as $\mathrm{T}_{1}\left(60 \%: 15 \%: 25 \%\right.$,) $\mathrm{T}_{2}$ (55\%:20\%:25,) $\mathrm{T}_{\mathbf{3}}(50 \%: 25 \%: 25 \%),, \mathrm{T}_{4}(45 \%, 30 \%, 25 \%$ ). The purpose of incorporating quinoa flour and lotus stem powder in selected utility food was to find out the best level of acceptance. The developed value added pizza base samples $\mathrm{T}_{0}\left(100 \%, 0 \%, 0 \%, \mathrm{~T}_{1}\right.$ (60\%:15\%:25\%,) $\mathrm{T}_{2}$ (55\%:20\%:25,) $\mathrm{T}_{\mathbf{3}}(50 \%: 25 \%: 25 \%),, \mathrm{T}_{4}(45 \%, 30 \%, 25 \%$,) were subjected to sensory evaluation (colour, flavour, texture, taste, appearance and overall acceptability) on nine point hedonic rating scale by panel of 30 members. On the basis of sensory evaluation results it was concluded that developed value added pizza base sample $\mathrm{T}_{3}$ (50\%:25\%:25\%) was highly acceptable among all the pizza base samples and further can be used as standardized pizza base sample for nutritional analysis. The nutrient content of standardized pizza base sample was assessed. The proximate composition analysis shows that the developed pizza base sample has $7.40 \pm 0.01 \mathrm{~g}$ moisture, $7.90 \pm 0.02 \mathrm{~g}$ fiber, $16.33 \pm 0.01 \mathrm{~g}$ protein, $1.83 \pm 0.05 \mathrm{~g}$ fat, $60.54 \pm 0.03 \mathrm{~g}$ carbohydrates, $13.81 \pm 0.07 \mathrm{~g}$ ash and $350.83 \pm 0.05 \mathrm{kcal}$ energy in it. The mineral content of the developed pizza base was $78.87 \pm 0.11 \mathrm{mg}$ calcium and $7.37 \pm 0.02 \mathrm{mg}$ iron. After baking the overall weight of pizza base was $115 \mathrm{gm}$ for 7 minutes baking time. On the basis of the above results it can be concluded that the developed value added pizza base is superior to normal pizza base nutritionally. 


\section{Introduction}

Bakery industry is one of the fastest growing food industries in the world. Bakery products such as pizza, cookies, biscuits, burger, bread and cake are most popular among them. These are most popular snacks for children and adults. In today's life style people prefer snack foods because of the light and quick meal that can be consumed anywhere and anytime as compared to the main course. Many people consume fast food in a way to prevent them from hunger. Pizza, burger, bread, biscuit, cookies, are eaten all over the world because of its simplicity and taste (Bijlwan et al., 2019). Day by day western culture is growing into the Indian society, and this is visible in the clothes that people wear, the food they consume and the lifestyles they lead. And one of the foods that Indians have become a fan of is the pizza. According to the Pizza Power 2013 State of Industry Report, the U.S., Brazil, Russia, India, and China are seen as emerging pizza markets in the world. The pizza market in India is worth over Rs 1,500 crores and has been growing at a consumer annual growth rate of 26 per cent for the last 5 years. In the pizza market, Domino's has captured over 55 per cent of the share in the organized pizza market and 70 per cent in the home delivery category. This year, Domino's opened its 1000th store in India and is planning to open its 2000th store by 2022 . This is the story of just one of the pizza vendors in India. There are many other pizza outlets such as Pizza Hut, Sbarro, Pizza Corner, and Slice of Italy that have expanded their reach in India. Although their market shares are not as huge as Domino's, they are still thriving despite an economic slowdown in India. There are many restaurants and fast food chains that sell pizzas because of the huge demand in the Indian market. Today, pizza bases, mozzarella cheese, pizza sauce, and other toppings are sold in almost every huge supermarket in India and those who prefer to make pizzas at home to suit their individual tastes can do so quickly. (https://www.mbarendezvous.com. 2020)

When we talk about Pizza, it is flat bread generally topped with tomato sauce, cheese and baked in oven. About its nutritional information, it contains high level of white flour, polyunsaturated fats and salts but lack protein, fibers, vitamins and minerals. For this reason, nutritionist, food connoisseurs have developed interest in this area for injecting fiber, protein, vitamins and minerals content in pizza. Largely pizza base is made with refined wheat flour, but it can be made by incorporating different value-added products. Value-added products are goods with an enhanced value stemming from some extra process or product such as incorporating pizza base with quinoa flour, lotus stem powder or any other to enhance its eating properties.

In the present research, to enhance quality of pizza quinoa flour is added. Quinoa (Chenopodium quinoa) seed plant is an annual broad leaved plant 1-2 meter tall with deep penetrating roots with can be cultivated from sea level up to an altitude of 3800 meter. Quinoa adapts to desert, hot and dry climates. This crop can grow with relative humidity from 40 percent to 80 percent. Although the ideal temperature for cultivating quinoa is between $15{ }^{\circ} \mathrm{C}$ and $20^{\circ} \mathrm{C}$, several investigations affirm that this plant tolerates maximum and minimum temperatures between $-4{ }^{\circ} \mathrm{C}$ and $30{ }^{\circ} \mathrm{C}$ respectively. It is resistant to low soil moisture, and can produce acceptable yields even with perceptions from 100 to $200 \mathrm{~mm}$. Due to its ability to adapt to adverse climate and soil conditions where other crops are unable to grow, harvest can be obtained at altitudes from sea level to $4000 \mathrm{~m}$. The cultivation of quinoa provides an alternative for countries with limited food production. The history of its human consumption reaches back 5000 years (oelke 
et al., 2012). Quinoa (Chenopodium quinoa) has been cultivated in the Andean region for several thousand years. Quinoa cultivation started in a few Indian states with the initial support from state governments, including Andhra Pradesh, Rajasthan and Uttarakhand. In 2013, the Project Anantha experiment was started in the districts of Hyderabad and Anantapur by the state government of the then Andhra Pradesh. During the rabi season of the year 2015-16.

Quinoa is grown in Bhilwara and Chittorgarh districts of Rajasthan in an area of 50 hectare. This yielded 18 quintals of quinoa per hectare. Quinoa (Chenopodium quinoa) is a plant species of the Chenopodiaceae family rich in high quality proteins, lipids, fiber, vitamins, and minerals. Quinoa also provides all essential amino acids necessary for human body. Apart that it has high amount of health beneficial phytochemicals like saponins, phytosterols and phytoecdysteroids. About its benefits, quinoa has given positive health effective on metabolic, cardiovascular and gastrointestinal in human body (Navruz and Sanlier, 2016).

Wheat (Triticum aestivum) is a "king of cereals" and one of the most important staple food crops. It is a cereal grain, a member of the grass (Triticum) family. It is cultivated worldwide. In India Uttar Pradesh, Madhya Pradesh, Punjab, Haryana, Maharashtra and Gujarat are major wheat growing states. Uttar Pradesh is the largest wheat producing state of India. The three major categories of wheat hard, soft and durum have a great variety in their nutritional aspects, specifically in their protein levels. Hard wheat has high protein and gluten levels which make it particularly useful for bread making. Wheat is milled to whole wheat flour for the production of unleavened flat bread locally known as "Chapati". Wheat flour as the major ingredient for bakery products has combinate other potential sources of flour for bakery products. Wheat grain is used to make flour for leavened, flat and steamed breads, biscuits, cookies, cakes, pasta and noodles because of its unique protein gluten which provides structural framework for spongy, cellular texture of bread and other baked products. Gluten provides a network of fibers that traps carbon dioxide and steam. Allowing for a light, porous by creating small pockets during baking. Wheat has several nutrition and health benefits. Whole wheat reduces the risk of heart diseases by lowering the cholesterol levels, blood pressure and reducing blood coagulation time. Wheat is rich in magnesium and vitamin $\mathrm{E}$ which helps in reducing the problem of asthma (https://www.glnc.org.au. 2020).

Nelumbo nucifera also known as Indian lotus, sacred lotus, bean of India, or simply lotus, it belongs to Nelumbonaceae family. It has a very wide native distribution, ranging from central and northern India. Almost all parts of the plant like the root, young flower, stalks, seeds, etc. are edible. Lotus stem also known as lotus root it is a root vegetable from India and China, which is used widely in Indian, Chinese and Japanese food. They are the edible parts of the lotus flower which is found under water. The stem is lime green in color with a whitish flesh. Lotus stem is very healthy being a great source of dietary fiber. It contains minerals like copper, iron, zinc, magnesium and manganese which help to boost the production of red blood cells. It has a high content of vitamin $\mathrm{C}$ which helps to protect our body from scurvy and increases immunity. Lotus stem is high in dietary fiber which is useful to keep the digestive system healthy.

According to Gnana (2014) lotus stem is an aquatic herb with stout creeping yellowish white coloured rhizome. The Rhizomes of Nelumbo Nucifera shows anti diabetic and 
anti-inflammatory effects. Its extracts showed antipyretic effect and leaves and stamens showed antioxidant effect and beside this, its seeds showed hepato-protective and free radicals scavenging effects. Lotus stem aqueous extract possess cyto-protective effect.

Extract contained polyphenolic compounds, which confer the radical scavenging and antioxidant activities on the extract and therefore protect the cells. The extract prevented the iron-induced oxidative damage (Takefumi et al., 2012)

\section{Materials and Methods}

The present study was carried out in the laboratory of Department of Food Science and Nutrition, College of Community and Applied Sciences (CCAS) and College of Dairy and Food Technology (CDFT), MPUAT, Udaipur.

\section{Preparation of quinoa flour}

Polished quinoa seeds (500gm) were cleaned and after that fine grinding were done. After grinding the powder was sieved $(300 \mathrm{~mm})$ and stored in airtight container at ambient temperature.

\section{Preparation of lotus stem powder}

Fresh lotus stems (4 kg) were afte that dirt and other field damage portion were removed from it. After the cleaning and washing the lotus stems were chopped in to small pieces with a knife and blanched in a hot water at $100^{\circ} \mathrm{c}$ for 3 minutes containing 2 per cent salt, water was drained and lotus stem were spread in tray, dried in solar dryer up to 5-10per cent moisture level for 9 hours. Dried lotus stems were cooled at room temperature. After cooling he fine grinding of the stems was done to make the powder. The powder was sieved (300 $\mathrm{mm})$ and stored in airtight container at ambient temperature.

\section{Preparation of pizza base}

The nutritious pizza base was developed by mixing of wheat flour, quinoa flour and lotus stem powder in four different ratios indicated as $\mathrm{T}_{1}(60: 15: 25), \mathrm{T}_{2}(55: 20: 25), \mathrm{T}_{3}(50: 25: 25)$ and $\mathrm{T}_{4}(45: 30: 25)$. The pizza base prepared only from wheat flour was taken as control $\left(\mathrm{T}_{0}\right)$. The developed pizza base samples were subjected to sensory evaluation. Nine point hedonic rating scale method was used for organoleptic evaluation of the products.

The results showed that sample $\mathrm{T}_{3}(50: 25: 25)$ was most acceptable with regards to all sensory parameters.

\section{Nutritional composition}

The standardized developed pizza base sample $\mathrm{T}_{3}$ and the control sample $\mathrm{T}_{0}$ were subjected to the nutritional analysis for comparison purpose. The AOAC (1990) method was used to determine moisture, crude fat, ash and crude fibre content. For determination of protein content Micro Kjeldhal method was used. Energy content was determined using physiological fuel value. Carbohydrate was determined using difference method. For determination of mineral contents (iron and calcium) titrimetric method (1951) was used.

\section{Results and Discussion}

Table 1 and 2 illustrate the findings about the proximate composition and minerals content (calcium and iron) of control $\mathrm{T}_{0}(100 \%, 0 \%$, 0\%, WF: QF: LSP) and standardized $\mathrm{T}_{\mathbf{3}}$ (50\%:25\%:25\%, WF:QF: LSP) sample. figure $1,2,3,4,5,6,7,8,9$ show the comparison between nutritive values of both the samples.

As a result of nutritional analysis we can conclude that higher energy was found in treatment $\mathrm{T}_{0}(100 \%, 0 \%, 0 \%$, WF: QF: LSP) $355.50 \mathrm{kcal}$ per $100 \mathrm{~g}$ on dry weight basis 
compare to treatment $\mathrm{T}_{\mathbf{3}}(50 \%: 25 \%: 25 \%$, WF: QF: LSP) $350.83 \pm 0.05 \mathrm{kcal}$ per $100 \mathrm{~g}$ respectively. The higher protein was recorded in treatment $\mathrm{T}_{3}$ (50\%:25\%:25\%, WF: QF: LSP) $16.33 \pm 0.01 \mathrm{~g}$ per $100 \mathrm{~g}$ respectively compare to treatment $\mathrm{T}_{0}(100 \%, 0 \%, 0 \%$, WF: QF: LSP) $8.89 \pm 0.02 \mathrm{~g}$ per $100 \mathrm{~g}$. The more fat content found in treatment $\mathrm{T}_{0}(100 \%, 0 \%$, 0\%, WF: QF: LSP) $3.24 \pm 0.01 \mathrm{~g}$ per $100 \mathrm{~g}$ compare to $\mathrm{T}_{\mathbf{3}}(50 \%: 25 \%: 25 \%$, WF:QF: LSP) $1.83 \pm 0.05 \mathrm{~g}$ per $100 \mathrm{~g}$. The higher carbohydrate recorded in treatment $\mathrm{T}_{0}(100 \%$, 0\%, 0\%, WF: QF: LSP) $70.13 \pm 0.01 \mathrm{~g}$ per 100 g compare to treatment $\mathrm{T}_{3}(50 \%: 25 \%: 25 \%$, WF: QF: LSP) 60.54 $\pm 0.03 \mathrm{~g}$ per $100 \mathrm{~g}$. The higher crude fibre found in treatment $\mathrm{T}_{\mathbf{3}}(50$ $\%: 25 \%: 25 \%$, WF:QF: LSP) 7.90 $\pm 0.02 \mathrm{~g}$ per $100 \mathrm{~g}$ compare to treatment $\mathrm{T}_{0}(100 \%, 0 \%$, $0 \%$, WF: QF: LSP) $1.30 \pm 0.01 \mathrm{~g}$ per $100 \mathrm{~g}$.
The higher iron content recorded in treatment $\mathrm{T}_{\mathbf{3}}$ (50\%:25\%:25\%, WF:QF: LSP) 7.37 0.02 mg per $100 \mathrm{~g}$ compare to $\mathrm{T}_{0}(100 \%, 0 \%, 0 \%$, WF: QF: LSP) $4.20 \pm 0.0 \mathrm{mg}$ per $100 \mathrm{~g}$. The higher calcium was found in treatment $\mathrm{T}_{\mathbf{3}}$

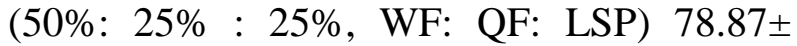
$0.11 \mathrm{mg}$ per $100 \mathrm{~g}$ compare to $\mathrm{T}_{0}(100 \%, 0 \%$, 0\%, WF: QF: LSP) $39.13 \pm 0.01 \mathrm{mg}$ per 100 $\mathrm{g}$.

The higher moisture content recorded in treatment $\mathrm{T}_{0}(100 \%, 0 \%, 0 \%$, WF: QF: LSP) $14.66 \pm 0.01$ percent $\mathrm{g}$ per $100 \mathrm{~g}$ compare to treatment $\mathrm{T}_{\mathbf{3}}(50 \%: 25 \%: 25 \%$, WF: QF: LSP) $7.40 \pm 0.01 \mathrm{~g}$ per 100 . The higher ash content found in treatment $\mathrm{T}_{0}(100 \%, 0 \%, 0 \%$, WF: QF: LSP) $15.30 \pm 0.01 \mathrm{~g}$ per $100 \mathrm{~g}$ compare to treatment $\mathrm{T}_{3}(50 \%: 25 \%: 25 \%$, WF: QF: LSP) $13.89 \pm 0.07 \mathrm{~g}$ per $100 \mathrm{~g}$ dry weight basis.

Table.1 Comparative proximate content of Control and $\mathrm{T}_{3}$ pizza base

\begin{tabular}{|c|c|c|}
\hline Nutrients & Control $\left(\mathbf{T}_{\mathbf{0}}\right)$ & Standardized $\left.\mathbf{( T}_{\mathbf{3}}\right)$ \\
\hline Moisture & $14.66 \pm 0.01$ & $7.40 \pm 0.01$ \\
\hline Crude Protein & $8.87 \pm 0.02$ & $16.33 \pm 0.01$ \\
\hline Fat & $3.24 \pm 0.01$ & $1.83 \pm 0.05 \mathrm{~g}$ \\
\hline Ash & $15.30 \pm 0.01$ & $13.81 \pm 0.07$ \\
\hline Crude Fiber & $1.30 \pm 0.01$ & $7.90 \pm 0.02$ \\
\hline Carbohydrates & $70.13 \pm 0.01$ & $60.54 \pm 0.03$ \\
\hline Energy & $355.50 \pm 0.01$ & $350.83 \pm 0.05$ \\
\hline
\end{tabular}

Table.2 Comparative mineral content of Control and $\mathrm{T}_{3}$ pizza base

\begin{tabular}{|c|c|c|}
\hline Nutrients & Control $\left(\mathbf{T}_{\mathbf{0}}\right)$ & Standardized $\left(\mathbf{T}_{\mathbf{3}}\right)$ \\
\hline Calcium & $39.13 \pm 0.01$ & $78.87 \pm 0.11$ \\
\hline Iron & $4.20 \pm 0.0$ & $7.37 \pm 0.02$ \\
\hline
\end{tabular}


Fig.1 Moisture content comparison of $T_{0}$ and $T_{3}$ pizza base samples

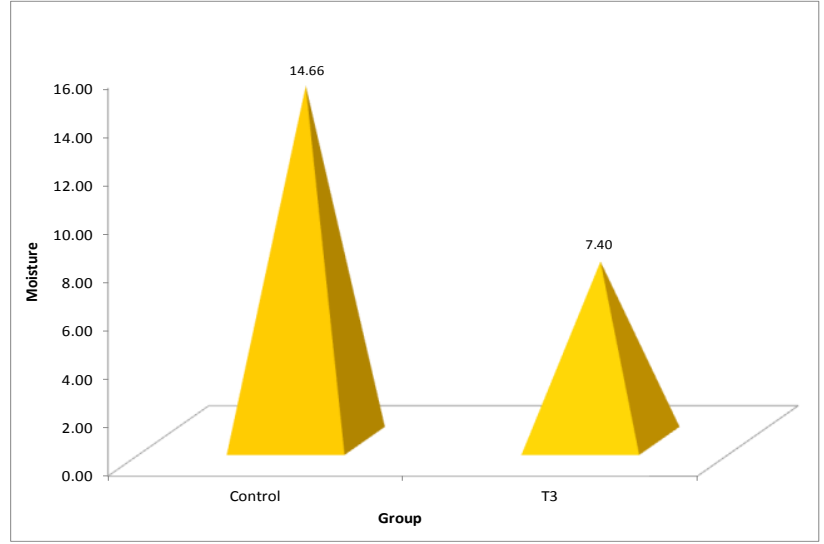

Fig.2 Protein content comparison of $\mathrm{T}_{0}$ and $\mathrm{T}_{3}$ pizza base samples

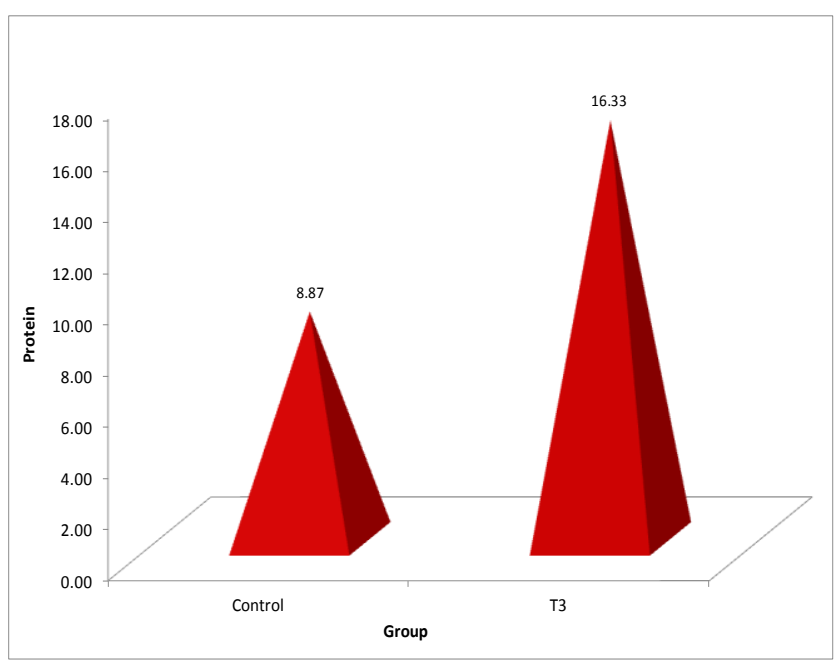

Fig.3 Fat content comparison of $\mathrm{T}_{0}$ and $\mathrm{T}_{3}$ pizza base samples

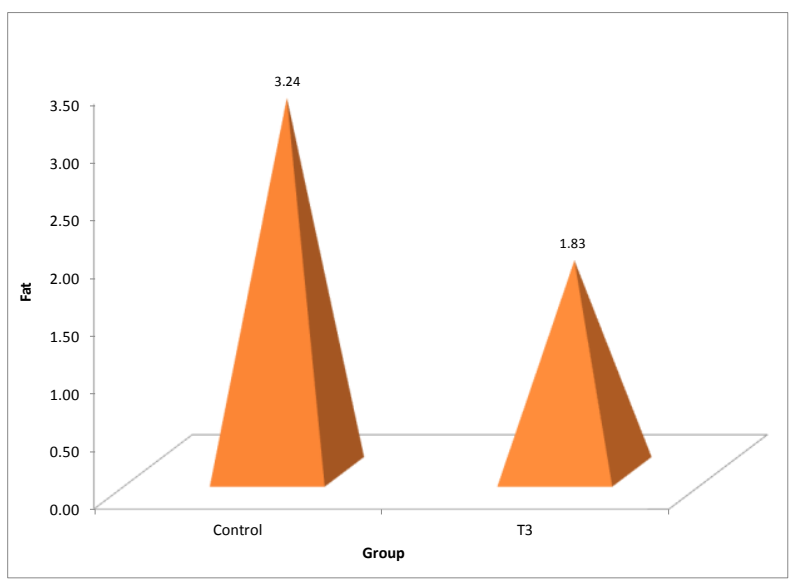


Fig.4 Ash content comparison of $\mathrm{T}_{0}$ and $\mathrm{T}_{3}$ pizza base samples

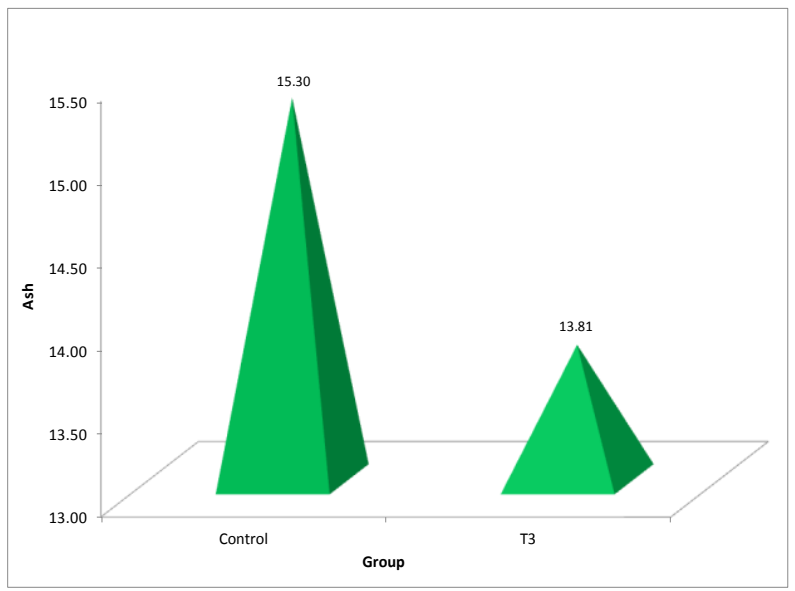

Fig.5 Fibre content comparison of $\mathrm{T}_{0}$ and $\mathrm{T}_{3}$ pizza base samples

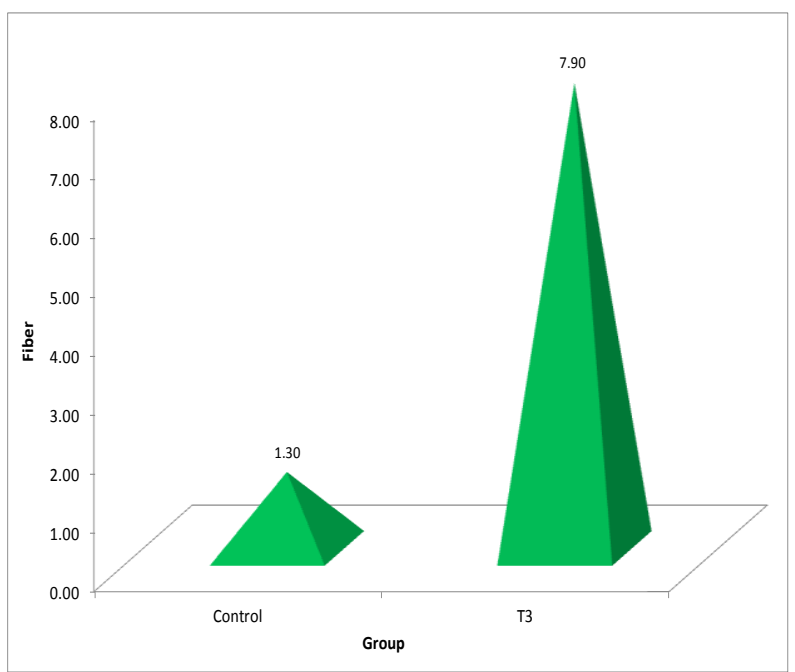

Fig.6 Carbohydrates content comparison of $\mathrm{T}_{0}$ and $\mathrm{T}_{3}$ pizza base samples

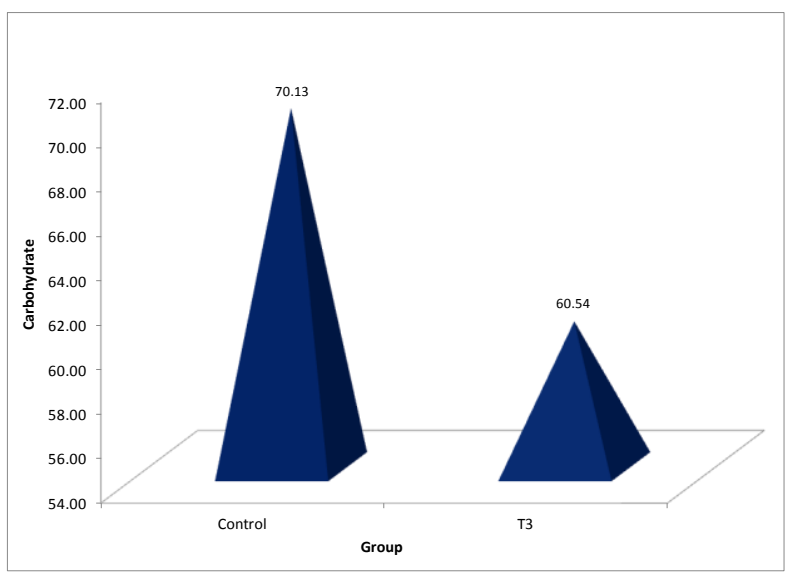


Fig.7 Energy content comparison of $\mathrm{T}_{0}$ and $\mathrm{T}_{3}$ pizza base samples

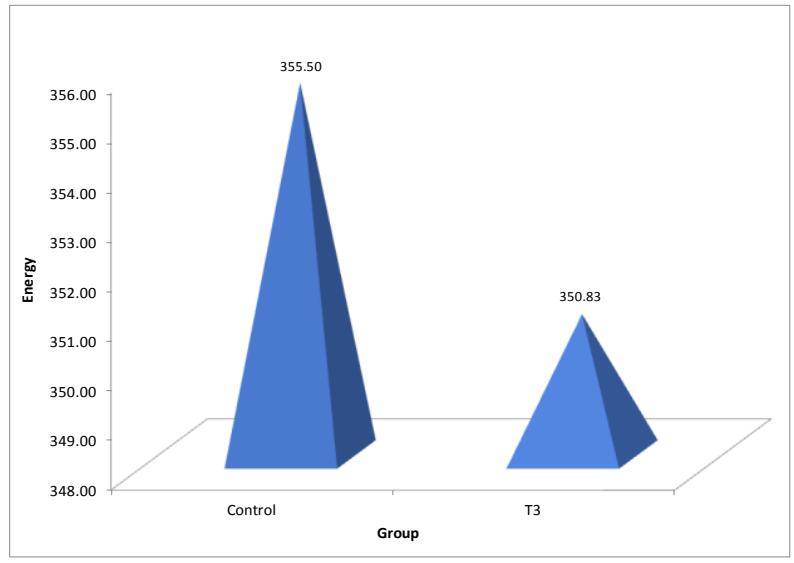

Fig.8 Iron content comparison of $\mathrm{T}_{0}$ and $\mathrm{T}_{3}$ pizza base samples

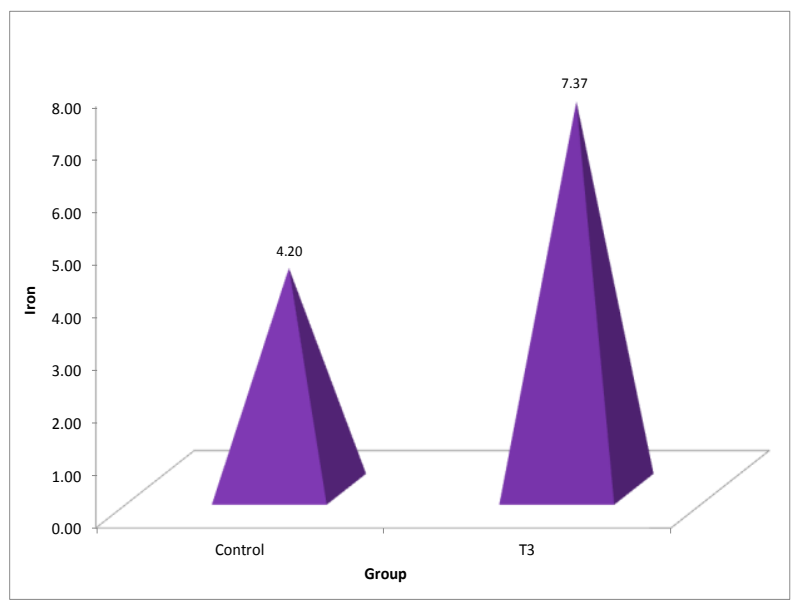

Fig.9 Calcium content comparison of $\mathrm{T}_{0}$ and $\mathrm{T}_{3}$ pizza base samples

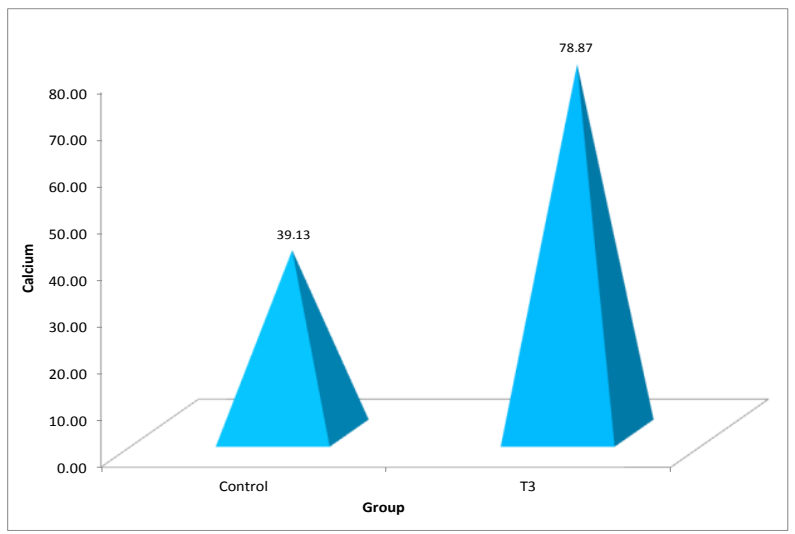

On the basis of the study we can conclude that the developed value added pizza base $T_{3}$ is more nutrient rich than the control pizza base
$\mathrm{T}_{0}$. It has higher amount of protein, fibre, iron and calcium where as lower amount of energy and carbohydrates as compared to control 
pizza base sample $T_{0}$. In present scenario when there is rise in non communicable disease such as obesity, diabetes and high blood pressure due to lack of nutrients in daily food routine the developed value added pizza base $\mathrm{T}_{3}$ may be helpful. Thus it can be a replacement for the conventional refined wheat flour pizza base which can cause serious health issues.

\section{References}

Pizza market in India, 2020.Retrieved Fromhttps://www.mbarendezvous.com general-awareness/pizza-market-inindia/on 01/07/2020.

Bijlwan, M., Naik, B., Sharma, D., Singh, A. and Kumar, V. 2019. Recent developments in dough based bakery products: A mini review. The Pharma Innovation Journal.8: 654-658.

Turkut, G.M., Cakmak, H., Kumcuoglu, S.and Tavman, S., 2016. Effect of quinoa flour on gluten-free bread batter rheology and bread quality. Journal of Cereal Science, 69:174-181.

Navruz V, S. and Sanlier, N. 2016.Nutritional and health benefits of quinoa. Journal of Cereal Science. 69:371-376.

Gnana Joyce, 2014. Estherlydia. Phytochemical Screening and Antioxidant Activity of Lotus (Nelumbo Nucifera) Stem. International Journal of Pharma and Bio Sciences. 5:385-393.

\section{How to cite this article:}

Saini Manju, Wadhawan Nikita and Lakhawat Sarla. 2021. Nutritional Composition of Developed Value-Added Pizza Base using Whole Wheat Flour, Quinoa Flour and Lotus Stem Powder. Int.J.Curr.Microbiol.App.Sci. 10(07): 620-628.

doi: https://doi.org/10.20546/ijcmas.2021.1007.067 